\title{
Pengaruh Pemberian Tempe Terhadap Kadar Malondialdehid Hati Mencit Jantan Putih yang di Induksi Timbal Asetat
}

\author{
Nurul Fadila ${ }^{1}$, Fadil Oenzil ${ }^{2}$, Endrinaldi $^{3}$
}

\begin{abstract}
Abstrak
Tempe adalah makanan berasal dari fermentasi kedelai dengan kandungan antioksidan yang dapat menghambat radikal bebas, seperti timbal. Malondialdehid (MDA) adalah indikator adanya radikal bebas. Tujuan penelitian ini adalah menentukan pengaruh tempe terhadap kadar MDA Hati Mencit Jantan Putih yang dipapar Pbasetat. Penelitian telah dilakukan di laboratorium Farmasi dan Biokimia Fakultas Kedokteran Universitas Andalas pada bulan April 2015 hingga Mei 2015. Perlakuan diberikan selama 4 minggu dengan menggunakan 25 ekor mencit jantan putih yang dibagi kedalam 5 kelompok yang terdiri dari: K1 kelompok kontrol negatif; K2 kelompok kontrol positif yang diberikan $\mathrm{Pb}$-asetat 40mg/kgBB/hari; P1 kelompok perlakuan dengan pemberian tempe sebanyak $5 \mathrm{~g} / \mathrm{kgBB} / \mathrm{hari}$ dan induksi Pb-asetat; P2 kelompok perlakuan dengan pemberian tempe sebanyak $10 \mathrm{~g} / \mathrm{kgBB} / \mathrm{hari}$ dan induksi Pb-asetat; dan P3 kelompok perlakuan dengan pemberian tempe sebanyak $20 \mathrm{~g} / \mathrm{kgBB} / \mathrm{hari}$ dan induksi Pb-asetat. Hasil penelitian menunjukkan kadar MDA hati kelompok $\mathrm{K} 1$ sebesar 4,95 nmol/ml, K2 sebesar 7,08 nmol/ml, P1 sebesar $6,73 \mathrm{nmol} / \mathrm{ml}$, P2 sebesar $5,32 \mathrm{nmol} / \mathrm{ml}$, dan P3 sebesar $6,26 \mathrm{nmol} / \mathrm{ml}$. Analisis uji Anova menunjukkan hasil yang signifikan $(p=0,000)$. Disimpulkan bahwa pemberian tempe dapat menurunkan kadar MDA hati mencit yang dipapar $\mathrm{Pb}$-asetat, dengan dosis tempe $10 \mathrm{~g} / \mathrm{kgBB} /$ hari yang mampu menurunkan kadar MDA hati bermakna secara statistik.
\end{abstract}

Kata kunci: tempe, MDA hati, timbal asetat

\section{Abstract}

Tempeh is an Indonesian fermented soybean which has benefits as antioxidant that prevents free radical. The free radical process itself is often triggered by chemicals such as lead content in air pollution. Malondialdehid (MDA) is the parameter to detect the free radicals. The objective of this study was to determine the effect of tempeh on MDA Hepar levels of white male Mice induced by lead acetate. This study was accomplished at the Laboratory of Pharmacy Faculty and Biochemistry Laboratory of Medical Faculty Andalas University held from April 2015 until May 2015. The study was conducted for 4 weeks using 25 white male mice which divided into 5 groups consisting of: K1 was the negative control group; $K 2$ was positive control group; $P 1$ was given tempeh doses of $5 \mathrm{~g} / \mathrm{kg} /$ day and induced by lead acetate; $P 2$ was given tempeh doses of $10 \mathrm{~g} / \mathrm{kg} /$ day and induced by lead acetate; and $P 3$ was given tempeh doses of $20 \mathrm{~g} / \mathrm{kg} /$ day and induced by lead acetate. The result showed that the MDA hepar level of negative control group is 4.95 $\mathrm{nmol} / \mathrm{ml}$. The MDA hepar level of positive control group was $7.08 \mathrm{nmol} / \mathrm{ml}$. The results of MDA hepar of each treatment group of $P 1, P 2$ and $P 3$ were $6.73 \mathrm{nmol} / \mathrm{ml}, 5.32 \mathrm{nmol} / \mathrm{ml}$ and $6.26 \mathrm{nmol} / \mathrm{ml}$ respectively. Those result showed that there were significant differences $(p<0,05)$. It can be conclude that the provision of tempeh affects the levels of MDA hepar in mice induced by lead acetate. The doses of tempeh that showed the optimum effect of reducing levels of MDA hepar was $10 \mathrm{~g} / \mathrm{kg} / \mathrm{day}$.

Keywords: tempeh, MDA hepar, lead acetat

Affiliasi penulis: 1. Prodi Pendidikan Dokter Fakultas Kedokteran Universitas Andalas Padang (FK Unand), 2. Bagian Biokimia FK Unand, 3. Bagian Kimia FK Unand
Korespondensi: Nurul Fadila, Email: nurulfadila@icloud.com,Telp: 085278580227 


\section{PENDAHULUAN}

Tujuh sumber utama pencemaran udara yaitu: Partikel debu/partikulat dengan diameter kurang dari $10 \mu \mathrm{m}$, Sulfur Dioksida (SO2), Ozon Troposferik, Karbon Monoksida (CO), Nitrogen Dioksida (NO2), Hidrokarbon $(\mathrm{HC})$ dan Timbal $(\mathrm{Pb})$. Sebagian besar zat tersebut berasal dari emisi kendaraan bermotor. Saat ini peningkatan kendaraan bermotor di Kota Padang rata-rata $12 \%$ per tahun. Pemerintah Kota Padang melalui Bapedalda melakukan uji emisi kendaraan bermotor. Hasil pengujian emisi kendaraan bermotor di Kota Padang pada tahun 2011 ditemukan bahwa kendaraan yang lulus uji emisi dengan bahan bakar bensin lebih banyak dibandingkan solar. ${ }^{1}$

Data $\mathrm{Pb}$ Udara di Kota Denpasar dalam kurun waktu tiga tahun yaitu, pada tahun 1998 sebesar $10,97 \pm 3,07 \mu \mathrm{g} / \mathrm{m}^{3}$, pada tahun 1999 sebesar 18,07 \pm

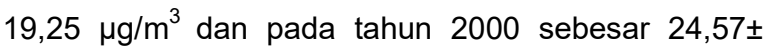
$7,96 \mathrm{\mu g} / \mathrm{m}^{3}{ }^{2}$ Kadar tersebut sudah melebihi nilai ambang keracunan timbal $\left(0,2 \mathrm{mg} / \mathrm{m}^{3}\right) .{ }^{3}$ Keracunan $\mathrm{Pb}$ juga terjadi akibat paparan $\mathrm{Pb}$ secara langsung dan tidak langsung, seperti pekerja di pertambangan dan pekerjaan yang berhubungan dengan cat. ${ }^{4}$

$\mathrm{Pb}$ masuk ke dalam tubuh melalui sistem pernapasan dan diserap langsung oleh kulit. Di dalam tubuh, $\mathrm{Pb}$ mempengaruhi enzim yang berhubungan dengan sintesis heme, transkripsi DNA, dan pelepasan neurotransmitter yang mengatur pertumbuhan dan memori sel. $\mathrm{Pb}$ juga mempengaruhi integritas membran, metabolisme steroid, sintesis vitamin $\mathrm{D}$ dalam sel tubulus ginjal, degenerasi akson dan demielinasi segmental. Manifestasi klinis toksisitas $\mathrm{Pb}$ secara kasar berkaitan dengan besarnya kadar $\mathrm{Pb}$ dalam darah. ${ }^{4}$

Pada keracunan $\mathrm{Pb}$ akan terjadi peningkatan Spesies Oksigen Reaktif (SOR). Munculnya SOR menyebabkan kerusakan oksidatif pada seluruh jaringan tubuh termasuk eritrosit yang mengandung lipid. SOR juga mengakibatkan peningkatan kepekaan struktur molekul penyusun membran sel yang terdiri atas kolesterol, fosfolipid dan glikolipid (yang keduanya mengandung asam lemak tidak jenuh) dan DNA terhadap radikal hidroksil. Sebagai akibatnya terjadi kerusakan sel dan banyak asam lemak peroksi yang terbentuk. ${ }^{5}$
Peroksidasi lipid itu sendiri merupakan mekanisme trauma sel, baik pada tumbuhan ataupun hewan, dengan demikian peroksidasi lipid digunakan sebagai indikator stres oksidatif pada sel dan jaringan. Endoperoksida lipid yang berasal dari asam lemak tak jenuh ganda bersifat tak stabil dan terurai membentuk beberapa senyawa kompleks termasuk senyawa karbonil reaktif, terutama Malondialdehide (MDA). Pengukuran MDA sering digunakan sebagai indikator peroksidasi lipid jaringan. ${ }^{6}$

Spesies oksigen reaktif dapat ditanggulangi dengan peran antioksidan yang berasal dari vitamin $\mathrm{A}$, C, E, makanan yang mengandung alkaloid, flavonoid, saponin, dan folifenol. Salah satu bahan makanan tradisional antioksidan yang sering kita konsumsi adalah tempe dengan bahan dasar kacang kedelai. ${ }^{7}$

Berdasarkan penelitian terdahulu diketahui bahwa tempe mengandung senyawa isoflavon, asam lemak esensial (linoleic acid, oleic acid dan linolenic acid), Zn dan $\mathrm{Cu}$. Kandungan tersebut dibutuhkan oleh enzim superoxyde dysmutase (SOD) untuk pertahanan pertama tubuh terhadap radikal bebas. Tempe terbukti dapat meningkatkan aktivitas katalase yang juga berfungsi sebagai enzim antioksidan pada tubuh. ${ }^{8}$ Mengonsumsi tempe juga dapat memperbaiki profil lipid sekaligus mencegah radikal bebas dengan biaya yang sangat terjangkau. ${ }^{9}$

Tempe merupakan makanan tradisional Indonesia yang mudah diolah dengan cara memfermentasikan kacang kedelai menggunakan jamur Rhizopus oligosporus dan Rhizopus oryzae. ${ }^{10}$ Tempe relatif mudah ditemukan serta secara ekonomi terjangkau bagi pembeli dan menguntungkan bagi pedagang. Di tingkat rumah tangga, tempe sangat mudah diolah menjadi berbagai jenis masakan. Sebagai pangan tradisional, tempe mempunyai komposisi gizi yang jauh lebih baik dibanding kedelai. ${ }^{9}$

Berdasarkan latar belakang yang sudah diuraikan diatas maka perlu diteliti bagaimana peran tempe yang mempunyai kandungan isoflavon terhadap stress oksidatif terkhusus organ hati sebagai organ detoksifikasi. Peneliti memilih hewan percobaan mencit sebagai model gambaran reaksi metabolisme yang nantinya pengukuran disetarakan dengan nilai yang terjadi pada tubuh manusia. 


\section{METODE}

Penelitian ini adalah eksperimental. Dengan menggunakan 25 ekor mencit jantan putih (Mus Musculus L.) berumur dua hingga tiga bulan, dengan berat badan antara 20 - 30 gram. Sebelum perlakuan, mencit tersebut diaklimatisasi selama satu minggu dengan pakan standar.

Mencit tersebut dibagi kedalam lima kelompok dengan masing-masing kelompok berjumlah lima ekor mencit. Kelompok tersebut adalah: K1 yaitu kelompok kontrol negatif yang hanya diberi pakan standar; K2 yaitu kelompok kontrol positif yang diberi $\mathrm{Pb}$-asetat dengan dosis 40mg/kgBB/hari; P1, P2 dan P3 yaitu kelompok perlakuan yang diberi $\mathrm{Pb}$-asetat dengan dosis $40 \mathrm{mg} / \mathrm{kgBB} /$ hari dan tempe dengan dosis 5 g/kgBB/hari, 10 g/kgBB/hari dan 20g/kgBB/hari.

Pemberian tempe dan $\mathrm{Pb}$-asetat dilakukan menggunakan spuit yang sudah dimodifikasi dengan ujung tumpul. Perlakuan dilaksanakan setiap hari selama empat minggu. Selama perlakuan mencit juga diberi pakan standar dan air minum ad libitum. Setelah empat minggu perlakuan, mencit kemudian dibunuh dengan anestesi eter secara inhalasi, kemudian dilakukan laparatomi untuk mengambil organ hati. Kemudian dilakukan homogenisasi menggunakan homogenizer. Homogena tersebut diambil sebanyak 0,5 ml untuk dilakukan pengukuran MDA menggunakan metode uji MDA-TBA menggunakan spektofotometer. Pengolahan data dan analisis data dilakukan secara komputerisasi melalui uji parametrik one-way ANOVA dan dilanjutkan dengan Post Hoc.

\section{HASIL}

Tabel 1. Hasil pengukuran MDA tiap Kelompok Perlakuan

\begin{tabular}{ccccccc}
\hline & \multicolumn{5}{c}{ MDA Hati (nmol/mI) } & $\begin{array}{c}\text { Nilai } \\
\text { Rerata }\end{array}$ \\
\cline { 2 - 5 } & I & II & III & IV & V & $\begin{array}{c}\text { MDA Hati } \\
\text { MDA }\end{array}$ \\
\hline K 1 & 4,97 & 4,83 & 4,97 & 5,23 & 4,73 & 4,95 \\
K 2 & 7,93 & 7,40 & 6,45 & 6,08 & 7,53 & 7,08 \\
P 1 & 6,32 & 7,18 & 7,56 & 6,40 & 6,17 & 6,73 \\
P 2 & 4,86 & 6,15 & 5,57 & 4,30 & 5,74 & 5,32 \\
P 3 & 6,69 & 6,84 & 5,48 & 5,87 & 6,42 & 6,26 \\
\hline
\end{tabular}

Hasil penelitian pada Tabel 1 terlihat bahwa rerata kadar MDA hati berbeda tiap kelompok. Nilai rerata kadar MDA hati terendah didapatkan pada kelompok kontrol negatif (K1), sedangkan tertinggi pada kelompok kontrol negatif yaitu mencit dengan induksi timbal asetat (K2).

Data hasil peneltian berdistribusi normal, sehingga dapat dilakukan uji Anova dengan hasil dapat dilihat pada Tabel 2 .

Tabel 2. Uji anova nilai MDA hati rerata kelompok hewan coba

\begin{tabular}{cccccc}
\hline Kelompok & $\begin{array}{c}\text { Rerata } \\
\text { (nmol/ml) }\end{array}$ & SD & Min & Maks & p \\
\hline K1 & 4,95 & 0,19 & 4,73 & 5,23 & \\
K2 & 7,08 & 0,78 & 6,08 & 5,23 & \\
P1 & 6,73 & 0,61 & 6,17 & 7,58 & $\mathbf{0 , 0 0 0}$ \\
P2 & 5,32 & 0,33 & 4,30 & 6,15 & \\
P3 & 6,26 & 0,57 & 5,48 & 6,84 & \\
\hline
\end{tabular}

Pada kelompok K2 terjadi peningkatan kadar MDA hati dibandingkan kelompok K1. Sedangkan pada ketiga kelompok perlakuan pemberian tempe (P1, P2, dan P3) terjadi penurunan kadar MDA hati terutama pada P2. Hal tersebut menunjukkan bahwa tempe memiliki pengaruh terhadap kadar MDA hati mencit yang diinduksi $\mathrm{Pb}$-asetat.

Analisis statistik dengan uji Anova yang pada Tabel 2 diatas didapatkan nilai $p=0,000$ atau $(p<$ $0,05)$ dengan derajat kepercayaan 95\%. Hasil ini menunjukkan bahwa terdapat perbedaan signifikan dari nilai rerata kadar MDA hati mencit pada kelompok penelitian yang hanya diberi pakan standar (K1), kelompok penelitian yang diberi $\mathrm{Pb}$-asetat saja (K2), kelompok penelitian yang diberi $\mathrm{Pb}$-asetat dan tempe dengan dosis $5 \mathrm{~g} / \mathrm{kgBB} /$ hari (P1), 10g/kgBB/hari (P2) dan $20 \mathrm{~g} / \mathrm{kgBB} / \mathrm{hari}$ (P3).

Hasil yang didapat, kemudian dilanjutkan dengan uji Post Hoc guna melihat perbedaan yang signifikan dari rerata kadar MDA Hati mencit pada tiap kelompok. Uji tersebut memberikan hasil terdapat perbedaan yang signifikan pada kadar rerata MDA hati antara kelompok: K1 dengan K2 $(p=0,000) ; \mathrm{K} 1$ dengan $P 1 \quad(p=0,002) ; K 1$ dengan $P 3 \quad(0,030) ; K 2$ dengan P2 (0,002); dan P1 dengan P2 $(p=0,17)$. Perbedaan antar kelompok yang lain tidak mempunyai perbedaan yang signifikan. 


\section{PEMBAHASAN}

Penelitian ini dilakukan terhadap 25 sampel mencit putih yang terdiri dari 1 kelompok kontrol negatif, 1 kelompok kontrol positif dan 3 kelompok perlakuan. Kelompok kontrol negatif adalah mencit yang hanya diberi pakan standar dan kelompok kontrol positif adalah mencit yang diinduksi timbal asetat $(\mathrm{Pb}$ asetat) sebanyak $40 \mathrm{mg} / \mathrm{kgBB} /$ hari. Sedangkan kelompok perlakuan pertama, kedua dan ketiga adalah mencit yang diinduksi $\mathrm{Pb}$-asetat dosis sama dengan kelompok kontrol positif dengan diberi tempe dosis berbeda yaitu $5 \mathrm{~g} / \mathrm{kgBB} /$ hari, $10 \mathrm{~g} / \mathrm{kgBB} /$ hari dan $20 \mathrm{~g} / \mathrm{kgBB} /$ hari. Perlakuan mencit dilakukan selama 4 minggu yang berlokasi di Laboratorium Farmakologi Fakultas Farmasi Universitas Andalas. Kemudian sehari setelah perlakuan dihentikan dilakukan anastesi menggunakan eter secara inhalasi. Kemudian dilakukan laparatomi dan organ hati diambil untuk pengukuran MDA hati mencit yang dilakukan di Laboratorium Biokimia Fakultas Kedokteran Universitas Andalas.

Hasil penelitian (Tabel 1) didapatkan nilai rerata kadar MDA hati mencit terendah pada kelompok kontrol negatif (K1) yaitu $4,95 \mathrm{nmol} / \mathrm{ml}$. Hal ini menunjukkan kadar MDA hati dalam batas normal karena pada mencit pada kelompok tersebut tidak diberi perlakuan. Sedangkan nilai rerata tertinggi didapatkan pada kelompok kontrol positif (K2)

MDA merupakan parameter untuk mengetahui tingginya kadar kerusakan jaringan akibat radikal bebas. $^{11}$ Dalam penelitian ini $\mathrm{Pb}$-asetat yang digunakan didapatkan dari Laboratorium Farmasi Universitas Andalas, sedangkan tempe yang digunakan adalah tempe yang dijual di pasar. Pemberian $\mathrm{Pb}$-asetat akan menyebabkan ketidakseimbangan antara jumlah oksidan dan antioksidan di dalam tubuh baik secara tidak langsung dengan menekan enzim yang berperan sebagai antioksidan pada tubuh seperti katalase, maupun secara langsung dengan peningkatan pembentukan spesies oksigen reaktif (SOR). ${ }^{12}$ Kedua hal tersebut pada akhirnya menyebabkan tubuh dalam keadaan stress oksidatif, dimana kadar oksidan menjadi lebih tinggi dari kadar antioksidan. SOR adalah kumpulan senyawa radikal bebas ataupun senyawa yang mudah menjadi radikal bebas dan dapat merusak membran sel dengan terjadinya peroksidasi lipid. ${ }^{13}$ Salah satu produk akhir dalam proses perokidasi lipid adalah MDA. $^{14}$ Kadar MDA yang tinggi menunjukkan meningkatnya proses peroksidasi lipid yang terjadi, dan proses peroksidasi lipid yang tinggi menunjukkan tingginya kadar radikal bebas dalam tubuh. ${ }^{11}$ Untuk mencegah terjadinya stress oksidatif maka dalam penelitian ini digunakan antioksidan eksogen yaitu tempe. ${ }^{7}$ Antioksidan tersebut diharapkan dapat menghambat terjadinya reaksi berantai radikal bebas sehingga secara tidak langsung dapat menghambat perusakan membran sel. ${ }^{15}$

Pada Tabel 2 terlihat bahwa kelompok K1 (kontrol negatif) dengan kelompok P1 (5g/kgBB/hari) yang diinduksi $\mathrm{Pb}$-asetat menunjukkan hasil terendah pada kelompok K1. Hal ini menunjukkan kadar MDA hati dalam batas normal karena tidak diberikan perlakuan pada kelompok K1. Hasil yang sama juga didapatkan pada perbandingan dengan kelompok P2 (10/kgBB/hari) dan P3 (20g/kgBB/hari).

Analisis kelompok K2 (kontrol positif) dengan kelompok P1 menunjukkan hasil lebih tinggi pada kelompok K2. Hasil yang sama juga didapatkan pada perbandingan dengan kelompok P2 dan P3. Hal tersebut sesuai dengan kepustakaan, dimana kandungan antioksidan pada tempe seperti Factor 2, genistein, daidzein dan glisitein mampu menekan radikal bebas yang berlebihan dalam tubuh. ${ }^{16}$ Dosis tempe pada penelitian ini didapatkan dari dosis lazim tempe yang dikonversikan terhadap berat badan mencit sehingga didapatkan kira-kira sebesar $13 \mathrm{~g} / \mathrm{kgBB} /$ hari. $^{8}$ Pada penelitian ini dosis yang digunakan adalah $10 \mathrm{~g} / \mathrm{kgBB} / \mathrm{hari}$ dan sebagai pembanding digunakan juga dosis $5 \mathrm{~g} / \mathrm{kgBB} / \mathrm{hari}$ dan dosis $20 \mathrm{~g} / \mathrm{kgBB} /$ hari.

Analisis antara kelompok $\mathrm{P} 1$ dan $\mathrm{P} 2$ menunjukkan bahwa kelompok P2 mempunyai kadar MDA hati lebih rendah, dengan nilai MDA hati mendekati kelompok kontrol negatif yang hanya diberi pakan standar. Hal ini sesuai dengan kepustakaan bahwa dosis tempe yang diambil mendekati nilai $13 \mathrm{~g} / \mathrm{kgBB} /$ hari untuk mencit dapat menetralisir secara optimal radikal bebas yang berlebihan di tubuh. ${ }^{8}$ Pemberian tempe tersebut didasarkan pada kondisi mencit yang berada dalam keadaan stress oksidatif dengan menggunakan $\mathrm{Pb}$-asetat. 
Dengan menambahkan dosis tempe menjadi 20g/kgBB/hari pada kelompok P3 ternyata memberikan hasil MDA hati yaitu $6,26 \mathrm{nmol} / \mathrm{ml}$ yang lebih tinggi dibandingkan nilai MDA hati $\mathrm{P} 2$ yaitu 5,32 $\mathrm{nmol} / \mathrm{ml}$. Hal ini menunjukkan keadaan stress oksidatif pada kelompok P3 lebih tinggi dibandingkan P2 karena konsumsi antioksidan dosis yang lebih tinggi dari dosis lazim dapat menurunkan efek antioksidan itu sendiri. Dosis tempe sebanyak $20 \mathrm{~g} / \mathrm{kgBB}$ masih memberikan berpengaruh untuk menurunkan kadar radikal bebas di dalam tubuh jika dibandingkan kadar MDA hati kelompok K2 yang tidak diberi tempe dengan hasil rerata MDA hati 7,08 $\mathrm{nmol} / \mathrm{ml}$.

Penelitian pengaruh pemberian tempe terhadap gambaran histopatologi hati mencit jantan putih yang terpapar $\mathrm{Pb}$-asetat ini telah dilakukan sesuai dengan prosedur yang seharusnya, namun masih terdapat beberapa keterbatasan penelitian. Keterbatasan tersebut adalah dosis tempe yang kurang bervariasi sehingga pada kelompok perlakuan belum terdapat nilai MDA hati yang sama dengan kelompok kontrol negatif.

\section{SIMPULAN}

Pemaparan Pb-asetat dengan dosis 40 $\mathrm{mg} / \mathrm{kgBB} /$ hari dapat meningkatkan kadar MDA hati mencit. Hasil data secara statistik menunjukkan perbedaan yang bermakna antara kelompok yang tidak terpapar dengan yang terpapar $\mathrm{Pb}$-asetat.

Hati mencit jantan putih yang diinduksi plumbum asetat saja $(\mathrm{K}+)$ pemberian tempe dengan dosis $5 \mathrm{~g} / \mathrm{kgBB} / \mathrm{hari}$ dan $20 \mathrm{~g} / \mathrm{kgBB} / \mathrm{hari}$ tidak menunjukan perbedaan bermakna, sedangkan pemberian tempe dengan dosis $10 \mathrm{~g} / \mathrm{kgBB} / \mathrm{hari}$ memperlihatkan perbedaan yang bermakna.

\section{UCAPAN TERIMA KASIH}

Terima kasih kepada Dekan Fakultas Kedokteran Universitas Andalas, pembimbing dan penguji, serta kepala dan segenap staff Bagian Biokimia FK UNAND dan laboratorium Farmasi UNAND Padang yang telah membantu terlaksananya peneltian ini.

\section{DAFTAR PUSTAKA}

1. Badan Pengendalian Dampak Lingkungan Daerah. Rekap hasil kegiatan upaya pengendalian pencemaran udara dari sumber bergerak (uji emisi kendaraan bermotor) di Kota Padang. 2011.

2. Badan Pengawas Obat dan Makanan (BPOM). Keracunan Timbal. BPOM (diunduh 20 April 2015). Tersedia dari: http://www2.pom.go.id/ public/siker/desc/produk/Timbal.pdf

3. Komunitas Mahasiswa Sentra Energi. 2008 (diunduh 23 Maret 2015). Tersedia dari: http:// www.kamase.org/?p=416

4. McGuigan MA. Chronic poisoning: trace metals and others. Dalam: Goldman, Shafer A, editor (penyunting). Goldman's Cecil Medicine. Edisi ke24. Philadelphia: Saunders; 2012.

5. Winarsi $H$. Antioksidan alami dan radikal bebas. Yogyakarta: Kanisius; 2007.

6. McKee T, McKee JR. Aerobic metabolism II: electron transport and oxidative phosphorylation. Biochemistry the molecular basis of life. Edisi ke-3. New York: McGraw-Hill; 2003.

7. Cahyadi W. Kedelai: khasiat dan teknologi. Jakarta: Bumi Aksara; 2007

8. Endrinaldi, Asterina. Pengaruh timbal (Pb) terhadap kadar MDA serum tikus putih jantan. Jurnal Kesehatan Andalas. 2014;3(3):531-5.

9. Utari DM, Rimbawan, Riyadi $H$, Muhilal P. Pengaruh pengolahan kedelai menjadi tempe dan pemasakan tempe terhadap kadar isoflavon. PGM. 2010:33(2):148-53.

10. Suharyono S. Pengaruh jenis tempe dan bahan pengikat terhadap sifat kimia dan organoleptik produk nugget tempe. Prosiding Seminar Hasil Penelitian dan Pengabdian Kepada Masyarakat. Bandarlampung: Universitas Lampung; 2006.

11. Christianto T. Radikal bebas dan diabetes melitus. Dalam: Pertemuan IImiah Berkala-I. IImu Penyakit Dalam; 1996.

12. Ercal N, Gurer H, Aykin-Burns N. Toxic metals and oxidative stress part 1: mechanism involved in metal induced oxidative damage. Current Top Medicinal Chemistry. 2001;6(1):529-39. 
13. Edyson. Pengaruh pemberian kombinasi Vitamin C dan $E$ terhadap kadar malondialdehid (MDA) pada eritrosit Rattus novergicus galur wistar yang diinduksi L-tiroksin (tesis). Surabaya: Universitas Airlangga; 2003.

14. Murray RK, Granner DK, Rodwell VW. Harper's illustrated biochemistry. 27th Ed. USA: McGrawHill Companies; 2009.

15. Jati SW. Efek antioksidan ekstrak etanol $70 \%$ daun salam (Syzygium polyanthum [Wight.] Walp.) pada hati tikus putih jantan galur Wistar yang diinduksi karbon tertraklorida (skripsi). Surakarta. Fakultas Farmasi Universitas Muhammadiyah; 2008. 